\title{
Poverty in Nigeria: A Social Protection Framework for the Most Vulnerable Groups of Internally Displaced Persons
}

\author{
Emmanuel Okokondem Okon ${ }^{1}$ \\ ${ }^{1}$ Department of Economics, Kogi State University, Anyigba, Kogi State, Nigeria \\ Correspondence: Department of Economics, Kogi State University, Anyigba, Kogi State, Nigeria, E-mail: \\ tonydom57@yahoo.com. Tel: +2348023275716
}

Received: January 12, 2018

Accepted: January 17, 2018

Online Published: January 28, 2018

\begin{abstract}
Despite strong economic growth in Nigeria, $54 \%$ of the population remains in poverty. Of significant concern is the fact that the poverty rate has doubled in the past 20 years. Internal displacement in Nigeria is a recurring and largescale phenomenon and has affected most of the country's 36 states. The country has seen many waves of displacement, both small and large scale, caused essentially by conflict, generalized violence, natural disasters and human rights violations all leading to loss of lives, properties and livelihood which in turn lead to deprivation, poverty and vulnerability. The operational definition of vulnerability in this paper as applied to the most vulnerable IDPs covers those categories of internally displaced persons who may never recover from the shocks of displacement and may become chronic poor as such worsening the poverty situation in Nigeria. This paper attempts a social protection framework for the most vulnerable IDPs as well as exit strategies. Protecting this vulnerable group is vital to poverty reduction especially as the country is presently suffering the adverse effects of dwindling revenue from crude oil and gas sectors, which today accounts for about 95 per cent of its revenue.
\end{abstract}

Keywords: Poverty, Social Protection Framework, Vulnerable Group, Internally Displaced Persons, Nigeria.

\section{Introduction}

Despite strong economic growth in Nigeria, $54 \%$ of the population remains in poverty. Of significant concern is the fact that the poverty rate has doubled in the past 20 years. Nigeria is also highly unequal: the Gini coefficient was 43.8 as of 2005 (Ortiz and Cummins, 2011). Approximately $20 \%$ of the population owns $65 \%$ of the national wealth (UNDP, 2009). Income inequality is just one dimension of poverty in Nigeria. Poverty and vulnerability are also highly influenced by social and other factors, including geography, ethnicity, age and gender. For instance, a low gender equality ranking reflects the inequalities in human capital, political representation and economic participation between women and men. Meanwhile, with over $60 \%$ of the population below 18, children are represented disproportionately in poor households. Nigeria's under-five mortality and maternal mortality rates for the poorest are among the highest in the world, and poverty and deprivation exacerbate child protection issues, including trafficking, prostitution and abuse (Hagen-Zanker and Holmes, 2012).Patterns of poverty vary by geographic location and are also influenced by socio-cultural and religious norms and prevalence of conflict, disaster, insurgence, terrorism and instability, as much as by economic environment.

Internal displacement in Nigeria is a recurring and large-scale phenomenon and has affected most of the country's 36 states. Africa's largest populated country has seen many waves of displacement, both small and large scale, caused essentially by conflict, generalized violence, natural disasters and human rights violations leading all leading to loss of lives, properties and livelihood which in turn leads to poverty and deprivation.

As at the end of 2014, of the global 38 million forcefully displaced by armed conflicts and generalized violence, Nigeria accounted for at least one million (Nigeriabar, 2015). Between July and October 2012, National Emergency Management Agency (NEMA) estimated in a published report that a total of 7.7 million people were affected by the flood disaster across the federation (Nigeriabar, 2015). Out of the affected population, 2.1 million people were internally displaced (IDPs); 363 persons died and 18,282 people were treated for injuries they sustained during the 
flooding. As at January 2014, about 165,000 people were displaced by both floods and conflicts in IDP camps in Nigeria (Nigeriabar, 2015).

Having recognized that in Nigeria and elsewhere in the world, IDPs are amongst the most vulnerable populations, the Federal Government of Nigeria signed and approved the ratification of the African Union (Kampala Convention) for the Protection and Assistance of IDPs in Africa. Similarly, in recent years, the government of Nigeria and its development partners have sought to develop social protection instruments as a mechanism to tackle high rates of poverty and vulnerability in the country and to support progress in both the economic and the social spheres (HagenZanker and Holmes, 2012).

It is against this background that this paper seeks to achieve a social protection framework for the most vulnerable groups of internally displaced persons in Nigeria. UNICEF defines social protection as "the set of public and private policies and programmes aimed at preventing, reducing and eliminating economic and social vulnerabilities to poverty and deprivation" (UNICEF, n.d.). Social protection is essential to the realization of the rights of children, women and families to an adequate standard of living and essential services. According to Bank (1997), protecting vulnerable groups during episodes of macroeconomic contraction is vital to poverty reductions in developing countries. This is essential to Nigeria as the country is presently suffering the adverse effects of dwindling revenue from crude oil and gas sectors, which today accounts for about 95 per cent of its revenue. The fallen price of crude at the world market has orchestrated the devaluation of the naira and increased inflation.

Poverty - and its common consequences such as malnutrition, homelessness, poor housing and destitution - is a major contributor to vulnerability. However, in this paper, the term vulnerability refers to the relationship between poverty, risk, and efforts to manage risk of falling into poverty. Though internally displaced persons are generally vulnerable, the operational definition of vulnerability here as applied to the most vulnerable IDPs covers those categories of internally displaced persons who may never recover from the severe shocks of the displacement and may become chronic poor, thus worsening the poverty situation in the country.

2. Conceptualizing Social Protection, Vulnerability and Poverty

Social protection emerged as a critical response to the "safety nets" discourse of the late 1980s and early 1990s. 'Safety nets' are a form of social protection which help people meet immediate basic needs in times of crisis. Typical short-term goals are to mitigate the immediate impact of shocks and to smooth consumption. The World Bank has a slightly different definition, which defines 'safety nets' as social assistance programmes (Gentilini et al., 2014).In the 1990 World Development Report, for instance, safety nets were very much the third prong of the World Bank's three-pronged approach to "attacking poverty" (World Bank, 1990), and were conceptualized as minimalist social assistance in countries too poor and administratively weak to introduce comprehensive social welfare programmes. During the 1990s, as thinking on livelihoods, risk and vulnerability, and the multi-dimensional nature of poverty became more nuanced, safety nets were increasingly criticized as residualist and paternalistic, and more sophisticated alternatives began to be proposed. At the same time, the broader potential of social protection began to be recognized, and bigger claims are now being made for what social protection can and should strive to achieve.

There are two interconnected strands in this response, both linked to a concern for long-term and sustainable poverty reduction. The first links risk management explicitly with economic growth, and argues that reducing risk or protecting the poor against income and consumption variability will allow them to invest and accumulate - a "trampoline" out of poverty (World Bank, 2000). Despite being vigorously promoted in international development publications, this link has not yet become a key component of anti-poverty programming in practice. In low-income countries, social protection continues to be perceived by governments and donors as comprising fiscally unsustainable "consumption" transfers to the economically inactive or unproductive poor, which diverts scarce public resources from "productive" investment for economic growth, and therefore deserves lower priority as a poverty reduction tool.

At the same time, most advocates of social protection do not make the second connection which we argue is of fundamental importance to long-term poverty reduction, namely the positive relationship between livelihood security and enhanced autonomy or empowerment. Social protection continues to be conceptualised by development agencies mainly in terms of public responses to livelihood shocks - the conventional, narrowly specified "safety net" function. But this is "economic protection", not "social protection", and it is hardly socially transformative. Largely missing from the World Bank's Social Risk

Management framework, for instance, is a concern for equity and social rights. It is argued that an appreciation of this second linkage can help create the policy conditions for a virtuous cycle of pro-poor growth, governance systems that are accountable and responsive to poorer as well as wealthier citizens, and an approach to development that is grounded in concerns for social equity. 


\subsection{Definitions and Types}

Some see social protection narrowly, essentially as a new label for old-style social welfare provided to the "deserving poor" (e.g. widows and orphans, or people with disabilities). Many policymakers continue to equate social protection with social safety nets, or interventions that cushion the poor against production and consumption shocks, such as food aid for drought-affected farmers in subsistence-oriented communities. Others adopt a very broad approach, including education and health subsidies, job creation and microcredit programmes, as well as safety nets for groups that may be vulnerable to shocks, but are not usually regarded as among the poorest strata of society. A more "political" or "transformative" view extends social protection to arenas such as equity, empowerment and economic, social and cultural rights, rather than confining the scope of social protection to targeted income and consumption transfers.

However, some current definitions of social protection from policy literature as given by some agencies are stated as follows: Social protection refers to the public actions taken in response to levels of vulnerability, risk anddeprivation which are deemed socially unacceptable within a given polity or society(Norton et al, 2000). Social protection is a collection of measures to improve or protect human capital, ranging from labor market interventions, publicly mandated unemployment or old-age insurance to targeted income support. Social protection interventions assist individuals, households, and communities to better manage the income risks that leave people vulnerable(World Bank, 2003).Social protection is the provision of benefits to households and individuals through public or collective arrangements to protect against low or declining living standards (Van Ginneken, 1999).Social protection is defined as the set of policies and programs designed to reduce poverty and vulnerability by promoting efficient labor markets, diminishing people's exposure to risks, and enhancing their capacity to protect themselves against hazards and interruption/loss of income(Ortiz, 2001).

2.2. Types of Social Protection

i)Social Assistance

Social assistance is direct, regular and predictable cash or in-kind resources transfers to poor and vulnerable individuals or households (Arnold et al., 2011). It is usually provided by the state and financed by national taxes (Barrientos, 2010). Support from donors is also important in lower income contexts. Transfers are non-contributory, i.e. the full amount is paid by the provider. Some are targeted based on categories of vulnerability, and some are targeted broadly to low-income groups. This is the primary form of social protection available in most developing countries (Barrientos, 2010).

Cash transfers: are direct, regular and predictable transfers that raise and smooth incomes to reduce poverty and vulnerability (Arnold et al., 2011:2). Unconditional Cash Transfers (UCTs) are for the beneficiary to decide how to spend. Conditional Cash Transfers (CCTs) are given with the requirement that the beneficiary meets certain conditions - often related to human capital development, such as visiting a health clinic or ensuring children go to school.

Social pensions: are state pensions, a form of cash transfer targeted by age. Pensions are the most common social protection tool, with the widest global coverage and often highest national spend.

In-kind transfers: are economic and livelihood asset transfers to households, facilitating income generation. They tend to be larger, one-off transfers but can also be smaller, regular transfers, such as food transfers. They tend to take an integrated approach, linking the transfer with skills training and other activities (Gsdrc, n.d.).

School feeding: is a free nutritious meal at school - usually lunch - and sometimes take-home rations for children most in need. This is a type of in-kind assistance. These are near-universal - most countries that can afford to provide food for their schoolchildren do so (Bundy et al., 2009). They help encourage parents to keep children in school (Norton et al., 2001).

Public works programmes (PWPs; or Public Employment Programmes): provide jobs on infrastructure projects for cash or food. They are sometimes classified as labour market interventions depending on whether their function is primarily poverty alleviation, job creation, or social protection. They are politically popular although arguably inefficient (Norton et al., 2001).

ii) Social insurance

These are contributory programmes where participants make regular payments to a scheme that will cover costs related to life-course events, for example, maternity, unemployment or illness (Barrientos, 2010). Sometimes costs are matched or subsidised by the scheme provider. Social insurance includes contributory pensions; health, unemployment, or disaster insurance; and funeral assistance (Norton et al., 2001). It can be provided formally through a bank or employer, or informally through a community-based pooled fund. Social insurance is strongly linked to the formal labour market, meaning coverage is often limited to formal workers. 
iii) Labor market interventions

Labor market interventions provide protection for poor people who are able to work, and aim to ensure basic standards and rights (Barrientos, 2010). Interventions can be active or passive:

Active labour market policies aim to help the unemployed and the most vulnerable find jobs, through interventions such as job centers, training, and policies to promote small and medium sized enterprises.

Passive interventions include maternity benefits, injury compensation, and sickness benefits for those already in work, financed by the employer. Passive interventions also include changes to legislation, for example establishing a minimum wage or safe working conditions.

Many poor people work within the informal sector, and some people with disabilities, the chronically ill and old may not be able to work at all, so labour market interventions cannot always reach them (Gsdrc, n.d.).

iv) Traditional or informal social protection

Formal social protection systems do not offer complete coverage and inevitably exclude parts of the population. Traditional community-based forms of social protection distribute risk within a community and fill some of the gaps left by formal interventions (Norton et al., 2001). They are often self-funded, for example funeral insurance savings groups, but can be externally funded by the state or donors. Formal social protection should be carefully managed to enhance, rather than disrupt, existing informal systems (Harvey et al., 2007).

v) Other types of social protection

Social care and support is highly complementary to social protection, and sometimes considered to be social protection, as a form of social assistance. UNICEF recognises that social support helps address the interaction between social and economic vulnerability, through services such as home-based care and family support services (UNICEF, 2012).

Government or private sector subsidies are sometimes classified as social protection if they enhance access for the poor or act as safety nets. Subsidies can keep prices low for basic goods and services consumed by the poor (Norton et al., 2001). However, subsidies are often regressive. The Middle East and North Africa spend four per cent of GDP on fuel subsidies, which represents a form of social assistance, but most of the benefit goes to upper-income groups (Gentilini et al., 2014).

Price support is state intervention to protect market prices for the goods produced by the poor, which can smooth income. There is a tendency for these temporary measures to become permanent, which institutionalizes unprofitable production (Norton et al., 2001).

2.3. Vulnerability and Poverty

Oxford Dictionaries (n.d.) defines vulnerability as the quality or state of being exposed to the possibility of being attacked or harmed, either physically or emotionally. In general terms, vulnerability expresses the propensity of an element or a set of elements (organized in a system) exposed to hazards to suffer damage. In other words, vulnerability allows the assessed level of hazard to be translated into an estimated level of risk (Sterlacchini, 2011). According to Devereux et al (2006), a common way of conceptualizing vulnerability is to view it as a product of two components: exposure to hazard (a shock or process) and resilience, or the ability to manage the hazard. Hazards could include natural shocks such as drought, or economic shocks such as currency depreciation. Resilience relates to 'coping strategies' at the individual, household, community and group levels. People can protect themselves against the risk that a hazard will undermine their livelihood by drawing on savings, diversifying their livelihoods to spread risk, building social networks that can provide informal social assistance in times of need, and so on. When all these risk-coping mechanisms fail, people become acutely vulnerable to even minor shocks.

It is important to emphasize that vulnerability and poverty are not synonymous. Specifically, vulnerability is a broader concept than poverty, in at least three ways: The non-poor are also vulnerable to future poverty (some definitions of vulnerability refer to people whose income is within, say, 20 per cent of the poverty line); Vulnerability incorporates various non-income aspects of ill-being, such as insecurity, social exclusion and political marginalisation, while poverty measures focus on income and assets; Vulnerability is a dynamic concept, which is both forward-looking and constantly changing, while poverty is a static concept that measures proxies for wellbeing at a point in time (Devereux et al, 2006).

Business Dictionary (n.d.) defined poverty as a condition where people's basic needs for food, clothing, and shelter are not being met. Poverty is generally of two types: (1) Absolute poverty is synonymous with destitution and occurs when people cannot obtain adequate resources (measured in terms of calories or nutrition) to support a minimum level of physical health. Absolute poverty means about the same everywhere, and can be eradicated as demonstrated by some countries. (2) Relative poverty occurs when people do not enjoy a certain minimum level of living standards as determined by a government (and enjoyed by the bulk of the population) that vary from country to country, sometimes within the same country. 


\section{Literature Review: Objectives and Impacts of Social Protection Programmes}

The primary aim for most social protection programmes is to reduce poverty and vulnerability. As noted above, different stakeholders have different conceptual approaches for achieving this. There is strong evidence that social protection can have significant impacts on both poverty and vulnerability. There is evidence of the positive effects of social transfers (in particular, social pensions and cash transfers) on poverty reduction and in reaching the chronically poor (Barrientos and Niño-Zarazúa, 2011). There is also evidence from Latin America that social transfers can reduce inequality (Fiszbein and Schady, 2009). There is some evidence that social protection also has negative effects on poverty indicators (Hagen-Zanker et al., 2011).

Many social transfers seek to improve children's schooling, to invest in human capital and to break the intergenerational transmission of poverty (Barrientos and Niño-Zarazúa, 2011). Impacts of social protection on schooling have included, at both primary and secondary levels, increased enrolment, attendance, better grade progression, and decreased drop-out (Barrientosand Niño-Zarazúa, 2011). A systematic review shows that both CCTs and UCTs have positive effects on schooling enrolment and attendance. The effect sizes are larger for CCTs than UCTs, but the difference is not significant (Baird et al., 2013). Social protection programmes which do not focus explicitly on schooling also have positive effects, for example, pensions are often used to pay grandchildren's school fees (Barrientos and Niño-Zarazúa, 2011).

While these immediate impacts are well-documented, there is less evidence on whether increased schooling translates into improved knowledge and educational attainment, better labour market outcomes, or an escape from chronic poverty (Barrientos and Niño-Zarazúa, 2011). The evidence on the effectiveness of CCTs and UCTs on improving test scores is small at best. More research is needed that looks at longer-term outcomes (Baird et al., 2013).

Social protection programmes can aim to improve health directly, e.g. by conditioning programmes on attendance at health services, or indirectly, e.g. through supplemented income and therefore consumption (Barrientos and NiñoZarazúa, 2011). There is strong evidence on the positive health impacts of cash transfers and health insurance programmes, particularly on children's and maternal health outcomes. Most of the evidence comes from CCTs in Latin America, since these are often conditioned on health investments. Many CCT programmes include a number of health components, including incentivising attendance for health education, measurements of height and weight, immunisations and nutritional supplementation.

CCTs in Latin America have had strong impacts on improving health care check-ups for children, children's morbidity rates and immunisation, among others (Barrientos and Niño-Zarazúa, 2011). CCTs have also improved maternal health (Barrientos and Niño-Zarazúa, 2011). A systematic review concludes that CCTs appear to be effective in increasing the uptake of preventative health services, and encourage some preventative behaviours (Lagarde et al., 2009). The link between CCTs and health outcomes is less clear. In some cases programmes have noted improvement in health outcomes, though it is unclear to which components these positive effects should be attributed (Lagarde et al., 2009). There is some evidence to suggest that MICs have been more successful at meeting health needs than LICs, as LICs often do not have the supply capacity to meet demand (Barrientos and NiñoZarazúa, 2011).

In theory, social protection has the potential to protect or improve the nutritional status of target groups in a number of ways. Improved economic status could enable households to access more nutritious diets, healthcare, and education, and to make improvements in water, sanitation and hygiene. All of these could help people remain wellnourished and to grow and develop properly. However, the evidence for the impact of social protection on nutrition remains mixed.

Evaluations of conditional cash transfer programmes in Latin America found that some, but not all, improved child growth (i.e. height). Only one looked at impact on wasting, but found no impact (Lagarde et al., 2009). These studies found that the age of the child and access to health care are more important for child growth than conditionalities (Manley et al., 2012). It has been suggested that 'nudging' beneficiaries (i.e.,emphasizing the importance of good nutrition but not attaching conditions) might be as effective. The evidence for unconditional cash transfers is also unconvincing (Ruel and Alderman, 2013). For example, evaluations of the Ethiopian Productive Safety Net Program have repeatedly found no discernible impacts on growth or risk for wasting among children in targeted households. Cash transfers, conditional and unconditional, have a slightly more positive effect on girls' nutrition than that of boys (Manley et al., 2012).

There have been relatively few evaluations of the impact of food transfers on nutrition outcomes. A recent set of studies comparing food with cash transfers found variation in effect in different countries (Hoddinott et al., 2013). Very generally, food transfers had more of an impact on energy intake whereas cash transfers had more of an impact on dietary diversity. Whilst this effect has been seen in other studies, it is not consistent in all settings and has generally not been related to subsequent changes in growth or risk of wasting. 
Recent reviews have shown that school feeding is not an effective way of improving nutrition outcomes, primarily because it fails to target children during the first 1000 days of their development (Alderman and Bundy, 2012). This is widely viewed as the critical window of opportunity for preventing malnutrition. There is emerging evidence that school feeding can have a positive impact on the nutrition of younger siblings. Whether this represents the most cost-effective way of achieving this outcome is debatable. Schools might provide a useful platform for promoting nutrition messages and for reaching adolescent girls (Bhutta et al., 2013). However, the benefits and risks of schoolbased nutrition programmes have not been tested.

4. Poverty Situation and Vulnerability in Nigeria

The majority of the Nigerian population lives in poverty, despite the wealth in the country. Although indications that poverty may be declining (AfDB et al., 2009; NPC, 2010), of significant concern is that, between 1980 and 2004, both rural and urban poverty more than doubled, from $28.3 \%$ to $63.3 \%$ in rural areas and from $17.2 \%$ to $43.2 \%$ in urban areas (UNDP, 2009). Nigeria's national poverty line states that $54 \%$ of the 140 million population lives in poverty (approximately 75 million people) (NPC, 2010), of whom $22 \%$ were defined as 'core poor', i.e. extremely poor in 2004 (UNDP, 2009).

Inequality in income and asset distribution, unequal access to basic infrastructure and services and social-cultural norms are key drivers of poverty, vulnerability and inequality in the country (UNDP, 2009). Indeed, Nigeria has high rates of inequality6. According to the UN Development Programme (UNDP, 2009), inequality increased between 1985 and 2004 (from 43 to 49), although others suggest it has been decreasing (from 49.1 in 1990 to 43.8)7 (Ortiz and Cummins, 2011): overall, however, it remains high. When adjusted to reflect inequality, Nigeria's Human Development Index value drops significantly, from 0.423 to 0.246 (UNDP, 2010).

Poverty incidence is highly correlated with educational attainment in Nigeria. Households headed by individuals with little or no education experience the highest poverty incidence, depth and severity (NPC, 2010; Ojowu et al., 2007). Nigeria has made improvements in net enrolment in primary school: 9 out of 10 eligible children are now in school as a result of Universal Basic Education (UBE) interventions and enrolment in private schools (NPC, 2010). However, this figure masks the fact that disadvantaged groups are still excluded and education quality remains poor: the country still has more than 7 million children out of primary school, of whom girls constitute about $62 \%$ (ibid.). It also masks attendance: the 2008 Demographic Health Survey (DHS) shows that net attendance at primary is 62.1\% (NPC and ICF Macro, 2009). Approximately 15 million children under 14 are working to support their family and pay their school fees (UNICEF Nigeria, 2006).

Although Nigeria's HIV prevalence appears to have stabilised in the past 10 years, the epidemic still remains a major public health challenge. The sheer size of the population means that Nigeria is second only to South Africa in terms of numbers of people affected by HIV and AIDS. Indeed, with an estimated 3.3 million people living with HIV, Nigeria bears nearly $10 \%$ of the global burden of HIV (UNAIDS, 2009).

Gender inequality is pervasive in Nigeria (Ajani, 2008). Women face consistent inequalities in terms of access to and control over land, credit facilities, technologies, education and health. Poverty therefore often affects women more intensely than men (Social Watch, 2005). In rural communities, female-headed households tend be the poorest, given cultural norms which inhibit women from inheriting land - traditionally, on the death of her husband, a widow is dispossessed of all her husband's property (Rural Poverty Portal, 2010). Incidence of food insecurity is also higher for female- than for male-headed households $-49 \%$ compared with $38 \%$ - although women improve household food and nutrition security by spending more of their income on food (Ajani, 2008).

As the median age in Nigeria is only 17.1 years (UNDP, 2010), and over $17 \%$ of the population is under the age of six (NPC and ICF Macro, 2009), poverty has tremendous impacts on children's protection needs. It threatens the survival of many Nigerian children, reflected in high rates of child and infant mortality; high prevalence of malnutrition; and often limited educational opportunities. Nigerian children are highly vulnerable to income poverty but also to a wide variety of other economic and social factors. These include urbanisation and migration; health shocks; environmental degradation; domestic violence and family fragmentation; broader societal violence and conflict; social exclusion and discrimination; harmful traditional practices based on cultural values; and orphanhood and loss of family.

4.1. Internal Displacement and Poverty in Nigeria

Nigeria currently has over four million internally displaced persons (IDPs) who have been forced to leave their communities and homes due to violent conflicts. We have the dubious distinction of being the third worst country in the world ranking of IDP numbers. Worldwide, the number of internally Displaced Persons (IDPs) according to International Displacement Monitoring Centre (IDMC) in 2013 stood at 33.3 million people(Ibrahim, 2014). Their spatial distribution shows that 63 percent of IDPs are located in only five countries affected by conflict - Syria (6.5 million), Colombia (5.7 million), Nigeria, (3.3 million), the Democratic Republic of Congo (2.7 million) and Sudan (2.4 million) (Ibrahim, 2014). Because these figures change in response to the conflict situation within countries, the 
caseload and therefore the ranking of the countries also change over time. The number of IDPs in Nigeria has grown considerably since the 2013 estimates and is today over four million.

The Boko Haram insurgency, conflicts with militants in the Niger-Delta, inter-community conflicts and cattle rustling in the north central zone (Plateau, Nassarawa and Benue States), rural banditry in the North West as well as election related violence (Kaduna, Zamfara, Katsina and Sokoto States) kidnapping in the South East and the 2013 flooding of River Benue have all conspired to provoke the displacement of millions of people from their normal places of abode. The most serious cause generating the increase of IDPs in the country is of course the insurgency in the North East zone. The current figure of the number of IDPs emanating from Boko Haram terrorism in the North East, according to the United Nations, is 1.5 million. There has been a spike in the numbers due to increased attacks and expansion of the zone of Boko Haram attacks and conquest of Nigerian territory over the past months (Ibrahim, 2014).

UNICEF has identified six major drivers of population movements in Nigeria leading to an increased need for humanitarian aid. They are insurgency, communal conflicts, natural disasters, environmental degradation, poverty and electoral violence. The key problem in Nigeria is that nothing is ever done to resettle the IDPs. The IDPs that ran from the post election violence of 2011 have not been resettled. Neither have the victims of the 2013 floods. The IDPs from the Boko Haram insurgency and inter-communal conflicts continue to grow partly because nothing is done to address their long-term needs.

IDPs live a life of misery after being uprooted from their homes and livelihoods. There are a few camps but they do not have good facilities such as rooms and toilets. Most IDPs have to seek out friends, relations and village mates to stay with. Others are dependent on religious organisations. Given the general poverty in the land however, taking care of IDPs is a real strain on hosts and host communities. Internally displaced persons have now become a part of the poverty stricken populace. Social protection is essential to the realization of the rights of internally displaced persons to an adequate standard of living and essential services.

5. Existing social protection policy and programmes in Nigeria

5.1. Social Protection Policy

There has been a concerted effort by governments and the international community in sub-Saharan Africa to foster commitment to social protection within national poverty reduction agendas. This resulted in the African Union's (AU's) Conference of Ministers of Social Development adopting a social policy framework that included a minimum package of social protection in October 2008, endorsed by AU Heads of State in early 2009, noting that 'social protection has multiple beneficial impacts on national economies, and is essential to build human capital, break the intergenerational cycle of poverty, and reduce the growing inequalities that constrain Africa's social and economic development' (Regional Experts Meeting on Social Protection, 2008). On this basis, AU Member States were called on to develop plans of action for the design and rollout of a minimum package of social protection measures. Despite Nigeria being a key player in the AU, the country has not yet achieved this(Hagen-Zanker and Holmes, 2012).

Hover, social protection policy has been discussed nationally in Nigeria since 2004, when the National Planning Commission (NPC), supported by the international community, drafted a Social Protection Strategy. More recently, in 2009, the National Social Insurance Trust Fund (NSITF) drafted a social security strategy. However, neither strategy has generated sufficient political traction to progress past draft, despite a chapter committed to social protection in the implementation plan of Nigeria's most recent national policy document - Vision 20: 2020 (HagenZanker and Holmes, 2012).

The draft 2004 Social Protection Policy approached social protection using a lifecycle and gender lens (recognizing both economic and social risks including job discrimination and harmful traditional practices) and presented a social protection response organized around four main themes: social assistance, social insurance, child protection and the labour market. However, only a few components of this are included in the national implementation plan of Vision 20: 2020, most notably social insurance, in the form of extending national health insurance to the informal sector; labour market programmes, including the development of labor-intensive interventions; and other social programmes, such as the provision of vitamin A supplements for children.

The Vision 20: 2020 objective for social protection is to 'increase productivity and income, reduce poverty and vulnerability by diminishing people's exposure to risk and enhancing their capacity to protect themselves against hazards and loss of income'. Specifically, it calls on social protection to contribute to reducing the poverty rate from $65 \%$ to $50 \%$ by 2013 . An estimated N186 billion of social protection expenditure was proposed over the plan period (2010-2013), although it is not clear how this will be allocated within social protection or how these resources will be generated. The plan suggests that process issues will be addressed (harmonising provision, improving coordination and data management, etc.) alongside expansion of social protection provision to the informal sector, particularly through the NHIS and social transfers to the most vulnerable groups (Hagen-Zanker and Holmes, 2012). 
Overall, limited federal-level leadership promoting the provision of a social protection package (beyond cash transfers and health financing mechanisms) and absence of an overarching federal social protection policy or strategy are key constraints to the development and implementation of appropriate social protection mechanisms at state level. Moreover, in practice, programmes have to date been based on a narrow conceptualisation of social protection (CCTs and health financing mechanisms) resulting in ad hoc, small-scale and state-led programmes, with little coordination between sectors and between the state and federal level.

Other social assistance programmes are implemented in an ad hoc manner by a range of government ministries, departments and agencies (MDAs) at state level and/or funded by international donors. These include CCTs for girls' education (in Bauchi, Katsina and Kano, through the UK Department for International Development (DFID), the UN Children's Fund (UNICEF) and the World Bank), a child savings account in Bayelsa and a disability grant in Jigawa, plus various health waivers, education support (e.g. free uniforms) and nutrition support. HIV and AIDS programmes at state level also include social protection subcomponents, including nutrition, health and education support. Labour market programmes include federal- and state-level public works programmes, agricultural subsidies/inputs and youth skills and employment programmes - but these are not necessarily targeted at the poor(Hagen-Zanker and Holmes, 2012).

A certain amount of social equity legislation has been passed, which can be seen as part of the transformative social protection agenda: the Civil and Political Rights Covenant, the Economic, Social and Cultural Rights Covenant, the Convention on the Elimination of All Forms of Violence Against Women and the Convention on the Rights of the Child. However, not all states have passed these, and implementation is weak at best. There is limited, if any, conceptual link between the broader regulatory policies of equality and rights and social protection policies.

5.2. Issues in the Existing Social Protection Programmes in Nigeria

The mapping of Nigeria's emerging social protection sector identified a number of key issues. One of the key concerns is the limited coverage and reach of existing programmes. This is reflected in the small scale of programmes run by government and development partners (international agencies and NGOs) which cover between a few hundred households and a few thousand. While 140 million people live in poverty in the country, social protection programmes reach only a small fraction of the poor. This includes the federal-led MDGs-DRG safety nets - COPE and the MCH (see table below). Only the CBHIS has the explicit vision to reach 100\% of the poor (in the informal sector). This may be linked to the presidential mandate given to the NHIS to achieve universal health insurance coverage and access to health care for all Nigerians by 2015 (NHIS, 2010). However, the executive secretary of the NHIS has admitted there are enormous financial difficulties in extending such a scheme to the huge number of informal workers and those living in poverty, as well as challenges relating to the poor state of health infrastructure and human resource capacity within the health system, a lack of public awareness of the scheme and weak coordination and reluctance of state governments and LGAs to engage with the scheme (Gavrilovic et al., 2011).

Table 1: Coverage of Social Protection Programmes

\begin{tabular}{|c|c|c|}
\hline Programme & $\begin{array}{l}\text { Projected coverage: number of } \\
\text { households } / \% \text { of poor }\end{array}$ & $\begin{array}{l}\text { Actual coverage: number of } \\
\text { households } / \% \text { of poor }\end{array}$ \\
\hline COPE & \multicolumn{2}{|c|}{$\begin{array}{l}\text { 22,000 households/less than } 0.001 \% \text { of poor households nationally } \\
\text { (NAPEP, NPC and ICF Macro, 2009) }\end{array}$} \\
\hline CCT girls' education & $\begin{array}{l}\text { Kano - scaling up to all eligible girls in } \\
\text { LGAs where CCT is implemented }\end{array}$ & $\begin{array}{l}12,000 \text { girls, Kano } / 0.002 \% \text { of poor people in } \\
\text { Kano ( } 9.2 \text { million population; poverty } \\
\text { incidence approx. } 60 \%) \\
7,000 \text { girls, Katsina / } 0.001 \% \text { of poor people } \\
\text { in Katsina ( } 6 \text { million population; poverty } \\
\text { incidence approx. } 70 \%)\end{array}$ \\
\hline $\mathrm{MCH}$ & \multicolumn{2}{|c|}{$\begin{array}{l}851,198 \text { women and girls June } 2010 \text { (Phase } 1: 615,101 \text {, Phase } 2: \\
\text { 236,097)/less than } 0.01 \% \text { of the poor (assumption } 75 \text { million poor; } \\
\text { poverty rate } 54 \% \text { ) }\end{array}$} \\
\hline CBHIS & $\begin{array}{l}100 \% \text { informal sector workers (when fully } \\
\text { rolled out, expected to cover } 112 \text { million } \\
\text { Nigerians in informal sector (PATHS2, } \\
2010 \text { ) }\end{array}$ & Currently unavailable \\
\hline
\end{tabular}

Source: Holmes et al (2012).

6. Most Vulnerable Groups of IDPs

Internally displaced persons are "persons or groups of persons who have been forced or obliged to flee or to leave their homes or places of habitual residence, in particular as a result of or in order to avoid the effects of armed conflict, situations of generalized violence, violations of human rights or natural or human-made disasters, and who have not crossed an internationally recognized State border."On the other hand, vulnerability is the forward-looking state of expected outcomes, which are in themselves determined by the correlation, frequency and timing of realized 
risks and the risk responses. Households are vulnerableif a shock is likely to push them below (or deeper below) a predefined welfare threshold (e.g., poverty)(Heitzmann et al., 2002).

Although all persons affected by conflict and/or human rights violations suffer, displacement from one's place of residence may make the internally displaced particularly vulnerable. Following are some of the factors that are likely to increase the need for protection (Training on the Protection of IDPs (n.d.):

- Internally displaced persons may be in transit from one place to another, may be in hiding, may be forced toward unhealthy or inhospitable environments, or face other circumstances that make them especially vulnerable.

- The social organisation of displaced communities may have been destroyed or damaged by the act of physical displacement; family groups may be separated or disrupted; women may be forced to assume non-traditional roles or face particular vulnerabilities.

- Internally displaced populations, and especially groups like children, the elderly, or pregnant women, may experience profound psychosocial distress related to displacement.

- Removal from sources of income and livelihood may add to physical and psychosocial vulnerability for displaced people.

- Schooling for children and adolescents may be disrupted.

- Internal displacement to areas where local inhabitants are of different groups or inhospitable may increase risk to internally displaced communities; internally displaced persons may face language barriers during displacement.

- The condition of internal displacement may raise the suspicions of or lead to abuse by armed combatants, or other parties to conflict.

- Internally displaced persons may lack identity documents essential to receiving benefits or legal recognition; in some cases, fearing persecution, displaced persons have sometimes got rid of such documents.

The multiple socio-economic disadvantages mentioned above that internally displaced persons experience makes them vulnerable. However, the operational definition of vulnerability here as applied to the most vulnerable IDPs covers those categories of internally displaced persons who may never recover from the severe shocks of the displacement and may become chronic poor, as such worsening the poverty situation in Nigeria. However, the task of identifying the most vulnerable groups is not an easy one. Besides there are multiple and complex factors of vulnerability with different layers and more often than once it cannot be analyzed in isolation. Based on the operational definition of vulnerability which covers those categories of internally displaced persons who may never recovered from a severe shock and are described as chronic poor, the following are identified as most vulnerable:

-disabling illness

-Those that have lost all their assets

-Isolated elderly people

-Women

- Malnourished people

-Children and frail

-Unaccompanied children

- Children used in hostilities

- Physically challenged

- Destitute people

-People living with AIDS

-Terminally ill

- Widow

-Chronic mental conditions

- Pregnant and nursing women

-The visually impaired

-Women suffering from VVF

-Those struggling with substance abuse

-Homeless persons

- Those maimed

-Those with low/no levels of education

-The unemployed

6.1. Social Protection Framework for the Most Vulnerable Groups of IDPs

In light of the challenges identified in the social protection programmes in Nigeria, this paper attempts to design a social protection framework for the most vulnerable groups of internally displaced persons. Drawing from Devereux and Sabates-Wheeler's (2004), the full range of social protection interventions can be categorized under protective, preventive, promotive and transformative measures: 
- Protective (protecting households' income and consumption, which includes social assistance programmes such as cash transfers, in-kind transfers, fee waivers to support access to basic and social services);

\begin{tabular}{lllll}
\hline $\begin{array}{l}\text { Vulnerability } \\
\text { Categories }\end{array}$ & $\begin{array}{l}\text { Examples of affected } \\
\text { groups }\end{array}$ & Leading indicators & $\begin{array}{l}\text { Category of } \\
\text { interventions }\end{array}$ & $\begin{array}{l}\text { Types of } \\
\text { programmes }\end{array}$ \\
& & & $\begin{array}{l}\text { Exit strategy } \\
\text { for most } \\
\text { vulnerable } \\
\text { people }\end{array}$ & \\
\hline
\end{tabular}

Social

Vulnerable
Children and frail

Blind children

Unaccompanied Children

proor nutritional status, low pre-schoo
proverage, child molestation

Children used in hostilities/Child soldiers

-Aggression, abusive, restless, stubborn, wild and harmful

-Social services - depression
Women/women suffering from VVF

Pregnant and nursing women

Widows

Destitute people

Physically challenged
- sexual assault and abuse, discrimination, - Social gender-based violence, human trafficking, insurance rape, wipe beating and corporal punishment, early marriage, genital mutilation

-slapping and kicking, no provision for antenatal care, poor oral hygiene -widow rites

-Neglect, harassment and abused

-Social insurance

- maltreatment, abuse

-Transformative action

- depression, recurrent infections, fatigue, vomiting

-depression, neglect, violence, abuse

- Social

insurance -Social assistance
-Social services

-guidance and counselling, taming,

-Free education, access to nutrition, school feeding, school transporting, provision of braile for communication, reading,etc.

- full scholarship, translating education acquired to livelihoods -guidance and counselling

-Free antenatal care

-empowerment, promotion of health right, skill acquisition

-access to school and learning, food for school, access to nutrition, access to health facilities, book allowance, school transporting/after school training.

-start-up funds,

-health awareness and care

-Single-parent allowances, cash transfer

- Start-up funds

-maternal benefit

- Start-up funds, Starter packs

-disability benefit

-Start up funds, Starter packs

-disability benefit 
Older blind/visually

impaired persons

Those maimed

Terminally ill

Sex workers

Isolated elderly

people/Aged

The homeless

Those struggling with substance abuse

People living with AIDS

Malnourished people

Victims of domestic abuse

Those with low/no level of education -maltreatment, deceived, misled, cheated, neglected, undermined, ignored,

harassment, abuse

-Loss of employment, depression, neglect, frustration

- poor health care, no health insurance coverage

-Violence, rape, kidnapping, murder, trafficking, slapped or stabbed

-neglect, physical abuse, financial fraud committed against them by relatives, strangers and caregiver

-hate crimes, killings, discrimination, criminalization of homelessness, victim of violence, accommodation problem

Sudden change in behavior, mood change, withdrawal from family members, sniffy or runny nose, unusual excitement, aggressiveness, delusion, hallucinations, depression

-stigmatization, discrimination, untold hardship

Weight loss, frequent infections, depression, tiredness, sluggish, poor vision at night or in dim light

-visible physical injuries, depression, alcohol or drug abuse

-Cannot read and write, no skill

- Social services
Social assistance

Social assistance

Ance to help in their disability needs counseling and guidance, vocational rehabilitation or trade

-Start up funds, Starter packs

-Job placement, start-up funds, starter packs

-disability benefit, skill acquisition

-Social assistance

- allowances

-Social assistance

-Skill acquisitions, training and entrepreneurship programme -health insurance

-Social services

-Transformative action

Transformative action

Prevention programme for drug abuse and violence, skill acquisition

-anti-retrovirals

(ARVs), counselling

-Transformative action services and financial support -community based therapeutic care programmes, health nutritional programmes

-Community based care, skill acquisition

-Transformative action

-Access to adult education, skill

-Transformative action
-Start-up funds, Starter packs

-low cost housing facilities, Start up funds,

-Start up funds, Starter packs

-free waivers for health care services

-microfinance

scheme

-old people's

home,

recreational

centre,

-low cost

housing

facilities, Start-

up funds, Starter packs

Starter packs

-allowance for purchase of supplements

-Start-up funds, starter packs

-Start-up funds, starter packs acquisition, training and entrepreneurship programme 


\begin{tabular}{|c|c|c|c|c|c|}
\hline $\begin{array}{l}\text { Economic } \\
\text { Vulnerable }\end{array}$ & $\begin{array}{l}\text { Female-headed } \\
\text { households }\end{array}$ & $\begin{array}{l}\text {-low income, low economic welfare - } \\
\text { low }\end{array}$ & $\begin{array}{l}\text {-Social } \\
\text { insurance }\end{array}$ & $\begin{array}{l}\text {-Crèches/pre-schools, } \\
\text { - }\end{array}$ & $\begin{array}{l}\text {-microfinance } \\
\text { scheme }\end{array}$ \\
\hline & \multicolumn{5}{|l|}{ Unemployed } \\
\hline & & $\begin{array}{l}\text {-wages, Inactivity (violence, substance } \\
\text { abuse), financial problems }\end{array}$ & -Social assistance & $\begin{array}{l}\text {-Unemployment } \\
\text { benefits, skill } \\
\text { acquisition, training } \\
\text { and entrepreneurship } \\
\text { programme }\end{array}$ & $\begin{array}{l}\text { Start-up funds, } \\
\text { starter packs, } \\
\text { job search and } \\
\text { linkage }\end{array}$ \\
\hline & $\begin{array}{l}\text { Those that have lost all } \\
\text { their assets }\end{array}$ & -low income, low economic welfare & $\begin{array}{l}\text { - Social } \\
\text { assistance }\end{array}$ & $\begin{array}{l}\text {-Unemployment } \\
\text { benefits, skill } \\
\text { acquisition, training } \\
\text { and entrepreneurship } \\
\text { programme }\end{array}$ & $\begin{array}{l}\text {-start-up capital, } \\
\text { starter pack } \\
\text {-microfinance } \\
\text { scheme }\end{array}$ \\
\hline
\end{tabular}

-Preventative (preventing households from falling into or further into poverty, including, for instance, health insurance programmes, subsidized risk pooling mechanisms);

-Promotive (promoting household's ability to engage in productive activities and increase incomes, for example through public works employment schemes, agricultural inputs transfers or subsidies); and

-Transformative (addressing social inequalities and discrimination, which includes, for example, core social protection programmes which tackle gender inequality and promote child rights and linkages to awareness-raising programmes or tackling discrimination).

Table 2: A Framework for Social Protection Programmes for the most Vulnerable Groups of IDPs in Nigeria

The framework above also shows how individuals or households can exit a social protection programme or graduate. The term graduation is used to mean graduating out of poverty. However, not all social protection programmes aim to graduate beneficiaries (e.g. pensions), and some households lack graduation potential (e.g. those with chronically sick members) (Garcia and Moore, 2012).

6.2. Roles and Responsibilities of Various Stakeholders

Key Stakeholders and their identified roles in the Social Protection for programme are:

a) Federal Government

-Provide necessary infrastructure and enabling logistics for effective implementation

-Provide financial and technical support at state and local government levels and as well monitor the performance of the programmes through its agencies

b) State governments

-Mobilization for effective participation

-Provide necessary infrastructure and enabling logistics for effective implementation

- Assist financially

c) Local governments

-Mobilization for effective participation

-Provide necessary infrastructure and enabling logistics for effective implementation

-Financial support

d)Local Communities

-They should initiate, develop and implement specific social protection projects in their communities

- They should render relevant infrastructural, human and material resources available

- They should help in the identification of the most vulnerable groups

e) Voluntary Agencies (Civil Society, CBOs, FBOs, etc).

- They should assist in initiate, develop and execute specific social protection projects in their communities

-They should provide relevant infrastructural, human and material resources

- They should assist in the identification of the most vulnerable groups

f) International Community/donor agencies 
-They should collaborate with the government in the implementation of some specific projects at the federal, state or local government levels.

-They provide and support capacity building to enhance the success of these social protection programmes

- They should also assist in monitoring and evaluating the social protection programmes as well as bringing in innovations

7. Conclusion

The many waves of displacement, both small and large scale, caused essentially by conflict, generalized violence, natural disasters and human rights have translated to an increase in the poverty levels in Nigeria. The internally displaced persons have now become a part of the poverty stricken populace. A social protection programme will go a long way in reducing poverty. Social protection programmes have been introduced in Nigeria but the effect has been minimal and the coverage does not adequately capture the core poor who in the case of displacement are the most vulnerable groups among internally displaced persons. Hence, the need for a social protection response that would stop internally displaced people falling into poverty; stop the most vulnerable IDPs falling deeper into poverty and against livelihood risks.

References

African Development Bank, UK Department for International Development, US Agency for International Development and World Bank (2009). 'International Development Association Country Partnership Strategy for the Federal Republic of Nigeria (2010-2013)'. Washington, DC: World Bank.

Ajani, O. (2008). 'Gender Dimensions of Agriculture, Poverty, Nutrition and Food Security in Nigeria'.NSSP Background Paper 4. Washington, DC: IFPRI.

Alderman, H., and Bundy, D. (2012). School Feeding Programs and Development: Are we Framing the Question Correctly? The World Bank Research Observer, 27(2), 204-221. http://dx.doi.org/10.1093/wbro/lkr005

Arnold, C., Conway, T., and Greenslade, M. (2011). Cash Transfers Literature Review. London: Department for International Development.

Baird, S., Ferreira, F. H. G., Özler, B., and Woolcock, M. (2013).Relative Effectiveness of Conditional and Unconditional Cash Transfers for Schooling Outcomes in Developing Countries: A Systematic Review. Campbell Systematic Reviews 2013:8. The Campbell Collaboration.http://www.campbellcollaboration.org/lib/project/218/

Barrientos, A. (2010). Social Protection and Poverty (Social Policy and Development Programme Paper Number 42). Geneva: United Nations Research Institute for Social Development.

Barrientos, A., and Niño-Zarazúa, M. (2011).Social Transfers and Chronic Poverty: Objectives, Design, Reach and Impact.Chronic Poverty Research Centre Report.http://www.chronicpoverty.org/uploads/publication_files/socialtransfersfullreport.pdf

Bhutta, Z. A., Das, J. K., Rizvi, A., Gaffey, M. F., Walker, N., Horton, S., Webb, P., Lartey, A., Black, R.E., Lancet Nutrition Interventions Review Group, \& Maternal and Child Nutrition Study Group (2013). Evidencebased interventions for improvement of maternal and child nutrition: what can be done and at what cost? The Lancet, 382(9890), 452-477. http://dx.doi.org/10.1016/S0140-6736(13)60996-4

Bundy, D., Burbano, C., Grosh, M., Gelli, A., Jukes, M., and Drake, L. (2009).. Rethinking School Feeding - Social Safety Nets, Child Development and the Education Sector. Rome: World Food Programme and World Bank. (Executive Summary).

Business Dictionary (n.d.). Poverty. http://www.businessdictionary.com/definition/poverty.html

Devereux, S., and Sabates-Wheeler, R. (2004).Transformative Social Protection, IDS Working Paper 232, Brighton: IDS.

Devereux, S, Baulch, B., Macauslan, I., Phiri, A. and Sabates-Wheeler, R. (2006).Vulnerability and Social Protection in Malawi . Institute of Development Studies at the University of Sussex Brighton BN1 9RE UK. IDS Discussion Paper 387

Fiszbein, A., and Schady,N. (2009). Conditional cash transfers. Reducing present and future poverty Policy Research Report, World Bank.

Gavrilovic, M., Alder, H., Cali, M., Cullen, E., Harper, C., Jones, N., Samuels, F. and Niño-Zarazúa, M. (2011)._The Impact of the Food, Financial and Fuel (3F) Crises on Women and Children in Nigeria'. London: ODI

Hagen-Zanker, J., and Holmes, R. (2012).Social Protection in Nigeria: Synthesis Report. ODI.https://www.odi.org/resources/docs/7583.pdf.

Hagen-Zanker, J., McCord, A., and Holmes, R. (2011). Systematic Review of the impact of Employment Guarantee Schemes and Cash Transfers on the Poor.London: ODI. http://www.odi.org/sites/odi.org.uk/files/odiassets/publications-opinion-files/7161.pdf 
Harvey, P., Holmes, R., Slater, R., and Martin, E. (2007). 'Social Protection in Fragile States.' Paper Prepared for OECD DAC Povnet. London: ODI.

Heitzmann, K., Canagarajah, R. S., and Siegel, P. B. (2002).Guidelines for Assessing the Sources of Risk and Vulnerability.Social Protection Discussion Paper Series. No. 0218, Social Protection Unit, Human Development Network, the World Bank.

Hoddinott, J., Gilligan, D., Hidrobo, M., Margolies, A., Roy, S., Sandström, S., Schwab, B., and Upton, J. (2013). Enhancing WFP's Capacity and Experience to Design, Implement, Monitor, and Evaluate Vouchers and Cash Transfer Programmes: Study Summary. Washington, DC: IFPRI. http://www.ifpri.org/sites/default/files/project_summary_final_july2013.pdf

Holmes, R. and Akinrimisi, B. with Morgan, J. and Buck, R. (2012) 'Social Protection in Nigeria: Mapping Programmes and Their Effectiveness'. Draft. London: ODI.

Garcia M, and Moore, C.M. 2012.The Cash Dividend: The Rise of Cash Transfer Programs in Sub-Saharan Africa. Washington D.C: The World Bank.

Gentilini, U., Honorati, M., and Yemtsov, R. (2014).The State of Social Safety Nets 2014.World Bank Working Paper.

Gsdrc (n.d.).Types of social protection. http://www.gsdrc.org/topic-guides/social-protection/types-of-socialprotection/

Ibrahim, J. (2014).Misery of Nigerian Refugees and Internally Displaced Persons. Premium Times.http://blogs.premiumtimesng.com/2014/12/22/misery-nigerian-refugees-internally-displacedpersons-jibrin-ibrahim/

Lagarde, M., Haines, A., and Palmer, N. (2009).The Impact of Conditional Cash Transfers on Health Outcomes and Use of Health Services in Low and Middle Income Countries. Cochrane Database of Systematic Reviews 2009, Issue 4. Art. No. CD008137. http://dx.doi.org/10.1002/14651858.CD008137.

Manley, J., Gitter, S., and Slavchevska, V. (2012). How Effective are Cash Transfer Programmes at Improving Nutritional Status?A Rapid Evidence Assessment of Programmes' Effects on Anthropometric Outcomes. London: EPPI-Centre, Social Science Research Unit, Institute of Education, University of London. http://r4d.dfid.gov.uk/PDF/Outputs/SystematicReviews/Q33-Cash-transfers-2012Manley-rae.pdf

National Planning Commission (2010). 'Nigeria: Millennium Development Goals (MDG), Countdown Strategy: 2010-2015'. Abuja: NPC.

National Planning Commission and ICF Macro (2009).Nigeria Demographic and Health Survey 2008: Key Findings. Abuja and Calverton, MD: NPC and ICF Macro.

National Health Insurance Scheme (2010)_NHIS-MDG/Maternal and Child Health (MCH) Project‘. Abuja: NHIS.

Nigeriabar (2015). Strategies for Adopting National Policy on IDPs .http://www.nigeriabar.com/2015/11/strategiesfor-adopting-national-policy-on-idps\#.Vx6cmtQrJdj

Norton, A., Conway, T., and Foster, M. (2000). 'Social Protection Concepts and Approaches: Implications for Policy and Practice in International Development', Working Paper 143, London: Centre for Aid and Public Expenditure, Overseas Development Institute (ODI)

Norton, A., Conway, T., Foster, M. (2001). Social Protection Concepts and Approaches: Implications for policy and practice in international development. Tech. rep., Centre for Aid and Public Expenditure, London, UK.

Ojowu, O., Bulus, H., and Omonona, B. (2007).'Nigeria Poverty Assessment'.www.paknigeria.org/pdfs/24_Nigeria_Poverty_Assessment_2007_Table_of_Contents_Executi.pdf.

Ortiz, I. (ed.), 2001, Social Protection in Asia and the Pacific, Manila: Asian Development Bank (ADB)

Ortiz, I. and Cummins, M. (2011). 'Global Inequality: Beyond the Bottom Billion. A Rapid Review of Income Distribution in 141 Countries'.Social and Economic Policy Working Paper. New York: UNICEF.

Oxford Dictionaries (n.d.).Vulnerability.https://en.oxforddictionaries.com/definition/vulnerability.

Ruel, M. T., and Alderman, H. (2013). Nutrition-sensitive Interventions and Programmes: How Can They Help to Accelerate Progress in Improving Maternal and Child Nutrition? The Lancet, 382(9891), 536-551. http://dx.doi.org/10.1016/S0140-6736(13)60843-0

Social Watch (2005).'The Many Programmes and the Many Poor'. www.socialwatch.org/node/10946.

Sterlacchini, S (2011).Vulnerability Assessment: Concepts, definitions and methods. Institute for the Dynamic of Environmental Processes. CHANGES-Workshop Meeting: Krakow, 22 September, 2011.

Training on the Protection of IDPs (n.d.). Who is an Internally Displaced Person? web.mnstate.edu/.../Who\%20is\%20an\%20Internally\%20Displaced\%20Pe..

US Agency for International Development (2009). 'HIV/AIDS in Nigeria: A USAID Brief'. Washington, DC: USAID. 
UN Children's Fund Nigeria (2006). 'Information Sheet: Child Labour.' Abuja: UNICEF.

UN Development Programme (2009). Human Development Report Nigeria 2008-2009: Achieving Growth with equity. Abuja: UNDP.

UN Development Programme (2010). Human Development Report. Geneva: UNDP.

$\begin{array}{llll}\text { UNICEF (2012).Integrated Social } & \text { Protection } & \text { Systems }\end{array}$

Unicef.www.unicef.org/socialprotection/.../Full_Social_Protection_Strategic_Fra...

UNICEF (n.d.).Social Protection Strategic Framework, Integrated Social Protection Systems: Enhancing Equity for Children.www.unicef.org/socialpolicy/.../UNICEF_Social_Protection_Strategic_Fr...

Van Ginneken, W. (ed.) (1999).Social Security for the Excluded Majority: Case Studies of

Developing Countries, Geneva: International Labour Office (ILO).

World Bank (1990).World Development Report 1990, Washington, D.C.: World Bank

World Bank (1997).Poverty Lines, Policy Research and Poverty and Social Policy Department World Bank, No. 6.Available athttp://www.worldbank.org/html/prdph/lsms/research/povline/pl_n06.pdf.

World Bank (2000).World Development Report 2000/2001, Washington, D.C.: World Bank

World Bank (2003).The World Bank and Social Protection in Latin America and the Caribbean.http://web.worldbank.org/archive/website00912B/WEB/OTHER/665B9E-

2.HTM?Opendocument

\section{Copyrights}

Copyright for this article is retained by the author(s), with first publication rights granted to the journal.

This is an open-access article distributed under the terms and conditions of the Creative Commons Attribution license (http://creativecommons.org/licenses/by/4.0/) 